\title{
Optimizing lowa land use: Past perspectives for current questions
}

\author{
J.F. Obrycki and D.L. Karlen
}

\begin{abstract}
Multiple tools exist today to guide sustainable land use, including soil maps, market analysis, and producer input, but we often forget they were also available in the past. During the 1930s hundreds of Iowa farmers met to discuss how to maintain productivity and reduce soil erosion. This review, based on three Iowa State University library sources that compiled county agricultural planning committee activities, provides useful perspectives for current agricultural land use questions. Ninety-seven percent of the committees concluded that less than half of the farmers in their respective areas were using land-improving practices, although $41 \%$ thought soil conservation and erosion control could be adequately addressed through individual actions. Corn (Zea mays L.) and soybean (Glycine max [L.] Merr.) were planted on 600,000 ha more than they recommended, while grasslands were grown on 900,000 fewer ha. The agricultural committees recommended rotations that most commonly included four crops but ranged from one (monoculture) to eight. Their discussions included recommendations for which crops were best for various soil series and/or landscape positions. There were no identifiable differences in crop rotation length across landscape position, with the most common rotation (45\%) being two years of corn, followed by oat (Avena sativa L.), and then one or more years of alfalfa (Medicago sativa L.). Crop production practices have changed since the 1930s. However, reexamining these discussions echoes contemporary soil and water conservation conversations and aligns with farmer response data regarding improving soil productivity, reducing nutrient losses, and maintaining economic vitality.
\end{abstract}

Key words: crop rotations-farmer surveys-Iowa-slope position

\begin{abstract}
What to produce, where to produce it, and which farming practices to use are agricultural questions requiring continuous evaluation and often resulting in evolving answers. To address those questions, effective farming systems must balance a range of soil and agronomic factors, including slope, soil type, drainage, tillage, crop sequence, and economic return; and balance the producer's time, energy, knowledge, skill, ability, and willingness to make changes. Soil erosion is one example of a timeless agricultural management issue that must be addressed (Bennett and Chapline 1928; Montgomery 2007). Reducing and controlling soil erosion was a primary motivating factor in the United States' nationwide soil conservation efforts, particularly in the 1930s (Nelson 1997; Helms et al. 1996; Walker and Brown 1936). The soil erosion survey conducted in Iowa found that erosion was widespread across the state with pronounced effects in
\end{abstract}

vation classes and plans were communicated to farmers. Land capability classes in combination with soil erosion calculations and judgements have also been used to estimate historical erosion rates from the 1930s and to project differences among various cropping systems (Helms et al. 1996).

Multiyear crop rotation was one of several land management approaches available to farmers in the 1930s who wanted to reduce soil erosion and maintain soil nutrient levels. Other practices included use of grassed waterways, contour farming, strip cropping, and terracing. Plot-scale soil erosion research conducted in Iowa during the period from 1933 to 1942 reported annual soil losses of between 83 and $112 \mathrm{Mg} \mathrm{ha}^{-1}$ for continuous corn (Zea mays L.) and $25 \mathrm{Mg} \mathrm{ha}^{-1}$ for a corn, oat (Avena sativa L.), and clover (Trifolium sp.) rotation (Browning et al. 1948). This erosion research was the basis for many land use conservation practice recommendations for Iowa (Browning et al. 1947). Crop rotations were a recognized soil conservation practice throughout agricultural history (Bullock 1992; Karlen et al. 1994) and can improve yield stability (Gaudin et al. 2015), agroecosystem functioning (Liebman and Schulte 2015), weed management (Liebman and Dyck 1993), and yield, often with minimum or even no fertilizer additions (Bullock 1992; Page and Willard 1947). Rotations may also provide greater economic returns, but this effect depends on the assumptions used in the calculations (Delate et al. 2003; DeVuyst et al. 2005; Chilcott 1910; Hays et al. 1912; Karlen et al. 1995, 2006).

Crop rotations by themselves are not sufficient to sustain soil resources. Furthermore, they may not be effective at all, as noted by researchers in the Canadian prairies during the early and middle twentieth century when annual rainfall was very low (Janzen 2001). Combining reduced tillage intensity with more diverse crop rotations has been shown to improve soil quality over time (Karlen et al. 2017; Jokela et al. 2011). However, excessive plowing, disking, or other intensive tillage practices between crops can reduce soil benefits (i.e., carbon [C] accumulation) accrued

John F. Obrycki is an Oak Ridge Institute for Science and Education (ORISE) Fellow and Douglas L. Karlen is a research soil scientist, both with the USDA Agricultural Research Service at the National Laboratory for Agriculture and the Environment in Ames, lowa. 
from an extended crop rotation, such as those occurring following multiple years of pasture or reduced tillage (Grandy and Robertson 2007; Necpálová et al. 2013; Reicosky et al. 1995). Furthermore, tillage generally creates a soil disturbance continuum with more aggressive practices disrupting long-term crop rotation benefits and leaving the soil prone to increased runoff and sediment loss (Reicosky 2015).

In addition to tillage frequency and intensity, the effect of crop rotations on maintaining productive agricultural systems and soils is also directly influenced by where rotations are used on the landscape. Soil changes due to landscape position under various cropping systems are generally most evident on exposed steeper slopes where water or wind erosion is most prevalent. An example presented by Beehler et al. (2017) showed that cereal rye (Secale cereale L.) increased soil particulate organic C on sloping and summit positions, but not in depressions. Similarly, using various combinations of tillage and slope position, Cambardella et al. (2004) found greater soil $\mathrm{C}\left(30 \mathrm{Mg} \mathrm{C} \mathrm{ha}{ }^{-1}\right.$ ) across slope position within a watershed managed using ridge tillage than in two other watersheds managed historically with moldboard plowing and more recently with deep disking (25 and $24 \mathrm{Mg} \mathrm{C} \mathrm{ha}^{-1}$, respectively). Across all three watersheds, foot-slope samples had higher soil quality index values compared to shoulder slope samples (Cambardella et al. 2004). Soil microbial properties were less affected by management practices when compared to interactive effects of management and landscape position, particularly for sloped areas (Wickings et al. 2016). Paired soil profile evaluations from pedons throughout Iowa indicated summit and backslope positions had greater topsoil losses than other positions. Some of this topsoil was translocated further down the slope and deposited, as evidenced by an increase of $42 \mathrm{~cm}$ in the depth to mollic colors within profiles for foot and toeslope positions (Veenstra and Burras 2015).

Erosion, crop rotations, and landscape position field management were only a few of the issues farmers faced in the 1920s and 1930s. In summarizing the efforts of the Iowa county agricultural planning committees, Folken (1937) noted the committees were working under several economic challenges. All available farmland in the country was already in farms, thus limiting farm expan- sion. Domestic and international markets for agricultural output were not growing quickly, potentially limiting farm incomes. The economic situation in the 1920s limited employment opportunities as well. Finally, farm ownership in Iowa was transitioning from owner-operated systems to tenantbased production. Three-fifths of all farm land in the state was rented and one-half of the farm families were tenants. With these issues in mind, the central question posed to the agricultural planning committees focused on cropping systems that would control erosion and maintain fertility (Folken 1937).

Passage of the Agricultural Adjustment Act in 1933 led to the creation of voluntary county agricultural committees in Iowa as a cooperative effort between Iowa State College's Extension Service and the Agricultural Adjustment Administration (Folken 1938). The Agricultural Planning Committees were formed in 1935 and consisted of 15 to 30 farmers in each of Iowa's 99 counties. The reason they were formed was to improve community understanding of how farmers were managing soils and crops at the landscape scale (Folken 1937). Additionally, these farmer committees were involved in discussions about the development of the state's soil conservation districts (Folken 1938).

This paper enhances the agricultural committees' results and conclusions from the 1930s with additional analysis pertaining to recommended crop rotations by landscape position. Additionally, the committees' survey responses are compared with current farmer survey responses to similar soil and water conservation questions. Though the data analysis methods have changed, the soil and water conservation questions remain strikingly similar. Folken (1937) noted each farmer committee was visualizing and recommending farming practices that would result in a "permanent agriculture best suited to the county's resources and people." This paper reexamines that episode in Iowa soil conservation history and provides an example that may be of interest to researchers in soil and water conservation regarding our continuing agricultural land use allocation questions that underlie stable agricultural systems.

\section{Materials and Methods}

This study utilized three sources available from the Iowa State University Parks Library in Ames, Iowa (County Agricultural Planning
Committees 1937; Folken 1937, 1938). Farmers in Iowa met at the county-level in 1936 and 1937 as members of agricultural planning committees to recommend farming practices that would keep the land productive. Their summaries were published in leaflets titled "Plan to Use Your Soil and Keep It Too" and distributed to farmers in each county (County Agricultural Planning Committees 1937). Ninety of these leaflets are currently available on microfilm reports and in print. Herbert G. Folken, listed as an Iowa State College Extension Assistant, wrote an extension circular published in 1937 that summarized the results from these county agricultural planning committee meetings (Folken 1937). This circular may be available at other libraries that maintain a collection of university extension publications. Folken, identified later as the Secretary of the State Committee on County Agricultural Planning, provided a summary in 1938 of committee reports relating to land use recommendations and soil conservation districts (Folken 1938). Writing in 1938, he noted 90 leaflets were submitted to the State Planning Board Committee on Soil Conservation for their information and records (Folken 1938). This description suggests that no leaflets have been lost from the original submissions out of Iowa's 99 counties.

Each of the 90 leaflets followed a similar format. The reports included a table of crop rotations grouped by soil series and several pages of instructions on how to best utilize the information on individual farms. The instructions suggested using terracing, contouring, grassed waterways, and strip cropping to protect the soil. The reports suggested farmers select rotations that fit their individual livestock and market situation, provided sufficient crop yields, and reduced soil erosion. County-level conservation practice recommendations, including estimates for the number of farms that would need to adopt certain practices such as applying lime and using grassed waterways, were included in each report as well. As Folken (1937) noted, the recommended practices and their respective areas were intended to keep soils productive and control erosion. The committees may also have been considering the economic and farm situation at the time (Folken 1937).

When making their recommendations, the committees focused on four land use classifications: intertilled crops, small grains, 
rotated grasslands, and permanent vegetation. Intertilled crops included corn, soybean (Glycine max [L.] Merr.), sorghum (Sorghum bicolor [L.] Moench), truck crops, and others. Truck crops included fruits and vegetables. Small grains included oats, wheat (Triticum aestivum L.), rye, barley (Hordeum vulgare L.), and others. Rotated grasslands included crops used in a rotation for improving the soil only and were kept in place for at most five years before plowing. Permanent vegetation included permanent pastures and meadows, timber, and game management areas (Folken 1937). Based on the descriptions of rotated grasslands and permanent vegetation, pastures or meadows that were plowed at intervals of five or fewer years would be considered rotated grasslands, and those that were plowed less frequently would be considered permanent vegetation.

When deciding how to allocate lands among the four classes (intertilled crops, small grains, rotated grasslands, and permanent vegetation), the committees identified first how many acres ( $1 \mathrm{ac}=0.405 \mathrm{ha})$ in each soil group should be kept in permanent vegetation. Next, they discussed how to distribute intertilled crops, small grains, and rotated grasslands among the remainder of the acres. When the committees were considering the total number of acres to assign to each practice, the number of acres in buildings, roads, water, etc. were deducted from the total number of acres in the county (Folken 1937).

The crop rotation by landscape position data presented in this study used data from a table found in each of the 90 leaflets titled "Land Use and Cropping Recommendations for Various Soil Types." An example of those tables is provided in figure 1. Each row was transcribed and evaluated for a different soil type. Therefore, throughout this paper, the term "soil type" refers to those rows from the land use and crop recommendation tables. Figure 1 contains four soil types. The term soil series refers to the individual soil series listed in the second column of the table (i.e., Shelby and Lindley in figure 1). When discussing results, the terms rotation and crop sequence are used interchangeably. Each county's recommendation table used the same format, although the length and complexity varied due to the number of soil types within a given category and the number of recommended rotations. Once transcribed for the 90 counties, there were

Figure 1

Example table from Audubon County, lowa, that was included in each county report from the 1930 s.

\title{
Land Use and Cropping Recommen- dations for Various Soil Types
}

\author{
Made by the County Agricultural Planning Committee
}

\begin{tabular}{|c|c|c|c|}
\hline $\begin{array}{l}\text { Percent } \\
\text { of Land } \\
\text { in } \\
\text { County }\end{array}$ & Soil Types & $\begin{array}{l}\text { Percent } \\
\text { Permanent } \\
\text { Vegetation }\end{array}$ & Rotations \\
\hline 15 & $\begin{array}{l}\text { Shelby silt loam } \\
\text { Shelby loam } \\
\text { Lindley silt loam } \\
\text { Lindley loam }\end{array}$ & 71 & $\begin{array}{l}\text { C-O-Cl } \\
\text { C-O-A-A-A-A } \\
\text { C-O-Cl-MH }\end{array}$ \\
\hline 24 & $\begin{array}{l}\text { Tama silt loam } \\
\text { Tama silt loam (shallow } \\
\text { phase) }\end{array}$ & 14 & $\begin{array}{l}\mathrm{C}-\mathrm{C}-\mathrm{O}-\mathrm{Cl} \\
\mathrm{C}-\mathrm{O}-\mathrm{Cl} \\
\mathrm{C}-\mathrm{C}-\mathrm{O}-\mathrm{A}-\mathrm{A}-\mathrm{A}-\mathrm{A} \\
\mathrm{C}-\mathrm{O}-\mathrm{Cl}-\mathrm{MHH}\end{array}$ \\
\hline 37 & $\begin{array}{l}\text { Marshall silt loam } \\
\text { Marshall silt loam (light } \\
\text { color phase) }\end{array}$ & 11 & $\begin{array}{l}\mathrm{C}-\mathrm{C}-\mathrm{O}-\mathrm{Cl} \\
\mathrm{C}-\mathrm{C}-\mathrm{O}-\mathrm{A}-\mathrm{A} \\
\mathrm{C}-\mathrm{C}-\mathrm{O}-\mathrm{A}-\mathrm{A}-\mathrm{A}-\mathrm{A} \\
\mathrm{C}-\mathrm{O}-\mathrm{A}-\mathrm{A} \\
\mathrm{C}-\mathrm{O}-\mathrm{Cl} \\
\end{array}$ \\
\hline 24 & $\begin{array}{l}\text { Bottom: } \\
\text { Terrace (2nd bottom) } \\
\text { Carrington loam } \\
\text { Waukesha silt loam } \\
\text { Judson silt loam } \\
\text { Wabash silt loam } \\
\text { Wabash silt loam (col- } \\
\text { luvial phase) } \\
\text { Wabash silty clay loam }\end{array}$ & 28 & $\begin{array}{l}\mathrm{C}-\mathrm{C}-\mathrm{O}-\mathrm{Cl} \\
\mathrm{C}-\mathrm{C}-\mathrm{O}-\mathrm{W}-\mathrm{Cl}\end{array}$ \\
\hline
\end{tabular}

*Legend; C-Corn, soybeans or other intertilled crops.

O-Oats or other spring sown small grain.

W-Winter wheat or other fall sown small grain.

$\mathrm{Cl}$-Clover or sweet clover.

A-Alfalfa.

MH-Mixed hay or rotation pasture.

(OScl)-Oats seeded to sweet clover-to be fall or spring plowed for intertilled crops the next year.

583 identified soil types, 146 unique crop rotations, and a total of 1,522 recommended rotations. Using the same land use and cropping recommendations data, Folken (1937) provided a different analysis of the results than just described. His approach and findings are discussed as well to provide context for this current study's methods.

The total land area under permanent vegetation for each county was calculated summing the product of percentage land (figure 1, column 1) and percentage permanent vegetation (column 3) for each soil type.
In 5 of the 583 listed soil types $(<0.1 \%)$, two percentages for percentage permanent vegetation were included within a single table row, potentially due to separation among individual soil series. These five instances occurred in five counties. If two permanent cover values were listed that appeared to correspond to separately listed soil series, then the average of these two permanent cover values was used to estimate land area under permanent vegetation for that soil type. In two cases, two permanent vegetation cover values were listed, but only one soil series 
Table 1

Soil series and other key words used in the 1930 committee reports organized into five contemporary landscape groups.

\begin{tabular}{llc}
\hline Landscape group & Soil series & Other key words \\
\hline Bottomlands (B) & Cass, Fargo, Genesee, Lamoure, Ray, Sarpy, Wabash & $\begin{array}{c}\text { Bottomland, marsh, meadow, muck, peat, } \\
\text { residual, riverwash }\end{array}$ \\
Terraces (T) & $\begin{array}{l}\text { Bertrand, Bremer, Buckner, Calhoun, Chariton, Davenport, Hancock, } \\
\text { Jackson, La Crosse, O'Neill, Osgood, Roseville, Waukesha }\end{array}$ \\
Upland, sloping soil (US) & Boone, Carrington, Clarion, Clinton, Dickinson, Dodgeville, Dubuque, \\
& Fayette, Gasconade, Judson, Knox, Lindley, Marshall, Miami, Plainfield, \\
Upland, outcrops (UO) & Shelby, Sioux, Sogn, Sparta, Tama, Union, Weller \\
Upland, level soil (UL) & Afton, Clyde, Conover, Edina, Floyd, Grundy, Marcus, Marion, Millsdale,
\end{tabular}

was noted. The vegetation cover value on the same line as the soil series name was used because details were lacking as to why two cover values were listed.

Crop rotations were grouped into 13 categories based on the initial two or three crops in each rotation (table S1 found at https:// doi.org/10.25380/iastate.6333104.v1). The number of crops included in a recommended sequence were counted based on the number of embedded dashes $(-)$, such that in figure 1 , the $\mathrm{C}-\mathrm{O}-\mathrm{Cl}$ rotation would be counted as three crops. Most likely the $\mathrm{C}-\mathrm{O}-\mathrm{Cl}$ sequence referred to corn, oat, and clover, but as noted, the letter " $\mathrm{C}$ " could also represent corn, soybean, or other intertilled crops, and the letter "O" could refer to oats or other spring-sown small grains. The recommended crop rotations can also be interpreted as crop sequences (i.e., intertilled crops, small grains, hay, or other crops) rather than exact prescriptions for what was to be grown. Furthermore, oat can also be planted in the fall as a cover crop. Some crop sequences were repeated in a given county for more than one soil type (table row in figure 1). Data for all crop rotations and unique crop rotations were generated for each county.

Originally, major soil types were grouped with their respective minor soil types (Folken 1937). For the current analysis, soil series were grouped by landscape position following the USDA NRCS Official Soil Series Descriptions (OSDs) (USDA NRCS 2017a). However, several soil series that existed in the 1930s (e.g., the Carrington series) no longer exist because they were reclassified over time (Riecken et al. 1948). Nicollet, a common soil throughout Iowa and Minnesota, was not included in the results because it was not described until 1949. If an OSD did not exist for a soil series, or if additional information was needed, historic soil surveys from the USDA NRCS were used (USDA NRCS 2017b). Additional classification data, such as the "terrace soils" landscape position description included in figure 1, were taken from the county committee reports.

Based on the landscape positions and language used in the 1930s reports and soil surveys, soil series were grouped into five categories, including bottomlands (B), terraces $(\mathrm{T})$, and uplands. Uplands were divided into sloping areas (US), level areas such as interfluves (UL), and outcrops (UO) (table S2 found at https://doi.org/10.25380/ iastate.6333104.v1). Soil series were grouped based on landscape position, parent material, and slope. This classification reflects general slope position using both current and historic information. Soil series and their respective slope positions are listed in table 1. Recommended crop rotations for a given soil series, or groups of soil series such as the "Bottom" soils grouped in figure 1, were assigned to a landscape position based on the landscape position for that soil series. Rotations could be listed in more than one landscape position.

Spatial data, including county shapefiles and county land areas were used from the Topologically Integrated Geographic Encoding and Referencing (TIGER) database (US Census Bureau 2017). The specific file downloaded was the 2016 County and Equivalent file. ArcGIS 10.4.1 (Esri, Redlands, California) was used for mapping. Agricultural data were compiled for the late 1930s (1938 to 1940) and present (2014 to 2016) using applicable Census of Agriculture data (USDA 2012a, 2012b, 2012c, 2012d, 1940a, 1940b, 1940c, 1940d) and yearly production data (USDA NASS 2018). All transcribed data are available (https://doi. org/10.25380/iastate.6333104.v1) and were analyzed using Microsoft Excel (v. 2013) and R (R Core Team 2017).
The results and discussion are presented in three sections. First, Folken's analysis of the committee recommendations is summarized to document how these data were originally used (Folken 1937). Next, the current crop rotation by landscape position analysis is presented to expand on Folken's results. Finally, farmer responses to soil and water conservation questions are compared between the agricultural committees (Folken 1938) and present day Iowa farmers using recent Iowa Farm and Rural Life Polls (Arbuckle 2013, 2016, 2017a, 2017b) for current perceptions. These polls are conducted annually with about 2,000 farm operators. This survey is a panel survey and contacts the same group of potential survey respondents each year (Iowa Farm and Rural Life Poll 2018). Collectively, these analyses demonstrate how farmerrecommended soil and water conservation practices from the 1930s and today are linked.

\section{Results and Discussion}

Folken's Analysis. Folken's (1937) analysis focused on the distribution of the four land use classifications; the types of rotations relative to the amount of time soil was under intertilled crops, small grains, and grassland; and land use recommendations by soil group. Folken was primarily interested in grouping responses by seven farming regions in the state, though he also included county comparisons as appendices (Folken 1937). Many of the regions were grouped by livestock uses, such as northeast dairy, western livestock, and south-central livestock. Across the entire state, $23 \%$ of the farmland (28\% of total county area when including buildings, cities, etc.) was recommended to be in permanent vegetation. The remaining $72 \%$ of land was recommended to be in rotated grass $(21 \%)$, small grain (21\%), and intertilled crops (30\%). Regional variation occurred in these land use recommendations. Counties in southern 
and southwest Iowa were recommended to have between $30 \%$ and $46 \%$ permanent vegetation, and counties in central Iowa were recommended to have $18 \%$ to $19 \%$ (Folken 1937). The areas with higher permanent vegetation cover experienced greater erosion rates (Walker and Brown 1936).

When analyzing the crop rotation recommendations, Folken (1937) focused on how the rotations distributed land use between intertilled crops, small grain, and grassland. For example, a rotation of $\mathrm{C}-\mathrm{O}-\mathrm{S}-\mathrm{W}$ was considered to be $50 \%$ intertilled crops (corn and soybean) and 50\% small grain (oat and wheat). Folken compiled a list of 29 recommended crop rotations (including one continuous corn) across all county reports and listed them by percentage time in each of these three land uses. Next, Folken averaged these land uses across all recommended rotations that were being applied to the $72 \%$ of land listed above. The recommended crop rotations distributed the three land uses to rotated grass (29\%), small grain (29\%), and intertilled crops (42\%). Across the seven state regions, rotated grass ranged from $23 \%$ to $37 \%$, small grain $25 \%$ to $31 \%$, and intertilled crops $36 \%$ to $46 \%$. Folken noted there were county-level variations in the recommendations, as locations in central and northwest Iowa had lower erosion risks than areas in western and southern Iowa (Folken 1937).

Next, Folken evaluated the recommended crop rotations by soil groups (figure 2). Though he presented average values, Folken noted there was a range of variation within the same soil group across the counties for recommended permanent vegetation cover. The soil series with the lowest recommended permanent vegetation cover and the higher percentages of intertilled crops were soils common to north-central Iowa on lower slope positions, including Webster, Marshall, Carrington, and Clarion. Soils more prone to erosion, such as Shelby and Lindley, were recommended to have greater percentages of permanent vegetation. Both these soils are located in potentially more erosion prone areas in the southern half of Iowa. Shelby soils occur in southwest Iowa, and Lindley occurs in southeast Iowa (Soil Series Extent Explorer 2018). These trends mirrored the county-level trends in permanent vegetation that Folken analyzed across the state (Folken 1937).

One of the final pieces of the report compared the committee recommendations to the statewide and county-level land use in 1929 and 1935 (Folken 1937). The recommendations were consistently lower in intertilled crops and higher for hay areas. Relative to 1929 crop data, the committee recommendations were $12 \%$ lower for intertilled crops, $4 \%$ lower for small grains, $27 \%$ higher for hay areas, and 9\% higher for all pasture. Compared to 1935 production data, committee recommendations were $8 \%$ lower for intertilled crops, 3\% lower for small grains, $45 \%$ higher for hay areas, and $1 \%$ higher for all pasture. In a later report, Folken (1938) compared the committee results to 1937 crop data and found a similar result. Committee recommendations were $13 \%$ lower for intertilled crops, $4 \%$ lower for small grains, and 44\% higher for grasslands. When the 1937 data were expressed as total hectares, intertilled crops were 600,000 ha above committee recommendations, small grains were 200,000 ha above the recommendations, and grassland was 900,000 ha below recommendations.

Folken (1937) recognized these recommendations were preliminary and contributed to land use discussions among farmers in these communities. This initial step of identifying how cropland use and soil conservation could look in each county was one piece of broader conversations about farm incomes, crop prices, and adopting conservation practices on individual farms Due to lack of time and data availability, the agricultural committees' efforts did not take into consideration how livestock production would have to change to meet the land use recommendations. Identifying types of soil conservation practices for each county was an initial step, but there were broader economic and social issues that would affect how these committee recommendations would be implemented (Folken 1937).

Linking 1930s Analysis to 2018 Analysis. The previous section described analysis conducted by Folken during 1937 and 1938 These results are important for understanding how the results were summarized and interpreted when they were collected. The land use recommendations were generated by farmer committees at a key agricultural and economic time for the United States. The agricultural committees were making recommendations that would protect soil, while also ensuring economic viability of farms. All of these recommendations and discussions were intended as a starting point, particularly reinforced by the subtitle to Folken's report (1937): “A First Approximation." The next sections of this paper provide what could be considered a second approximation of the agricultural committee recommendations by focusing on the crops included in the rotations and evaluating how crops varied by landscape position. The results conducted today are intended to supplement and expand on Folken's analysis.

Statewide Data. The average number of crops included in the recommended rotations was 4.2 , but ranged from 1 to 8 with a median of 4 . The number of rotational crops followed a normal distribution, with 3, 4 , and 5 being the most common (figure 3 ). The most frequently recommended starting points for the crop rotations were $\mathrm{C}-\mathrm{C}-\mathrm{O}$ (45\%) and $\mathrm{C}-\mathrm{O}-\mathrm{Cl}(24 \%)$ (table 2). Focusing on the first two crops, the $\mathrm{C}-\mathrm{O}-$ sequence (44\%) and the $\mathrm{C}-\mathrm{C}-$ sequence $(53 \%)$ were the most common. These two starting points accounted for $97 \%$ of all initial crop recommendations. Farmers in most counties recommended between 7 and 12 unique crop rotations (figure 4). Eleven counties included more than 12 and up to 25 different crop rotations. As Folken (1937) identified, the farm committees in southern Iowa recommended a greater percentage of land stay in permanent cover compared to committees in other parts of the state. Even with these regional variations in percentage permanent cover, the total number of recommended crop rotations remained consistent throughout the state. Figure 4 shows that the number of recommended crop rotations did not cluster in a similar manner to the percentage permanent cover data.

Landscape Position. Crop rotation length was consistent across landscape position with four crops being the most common. However, the percentage permanent cover varied by position (table 3). Bottomland and upland sloping areas had approximately $20 \%$ higher permanent cover than terrace and upland level areas. Bottomlands could have been wetter or less accessible for farm equipment, and upland areas with greater slopes would require greater proportions of landscape cover to protect soils. Relatively flat soils found in terrace and upland areas would have a greater likelihood of increased cropland use and a lower percentage permanent cover. These results are similar to those provided by Folken (figure 2) in which soils 
Figure 2

Table from Folken (1937) demonstrating the range in land use by common soil groups.

STATE

PERMANENT ROTATED SMALL INTERTILLED
VEGETATION GRASS GRAIN CROPS
\[ 28 \text { CR } \]

SOIL. GROUPS IN ORDER OF INCREASING PERMANENT VEGETATION WEBSTER

MUSCATINE

MARSHALL

CARRINGTON

GRUNDY

CLARION

TAMA

TERRACE SOILS

FAYETTE

CLYDE \& FLOYD

BOTTOMLAND SOILS

CLINTON

PEAT \& MUCK

SHELBY

KNOX

LINDLEY

MISC. SOILS
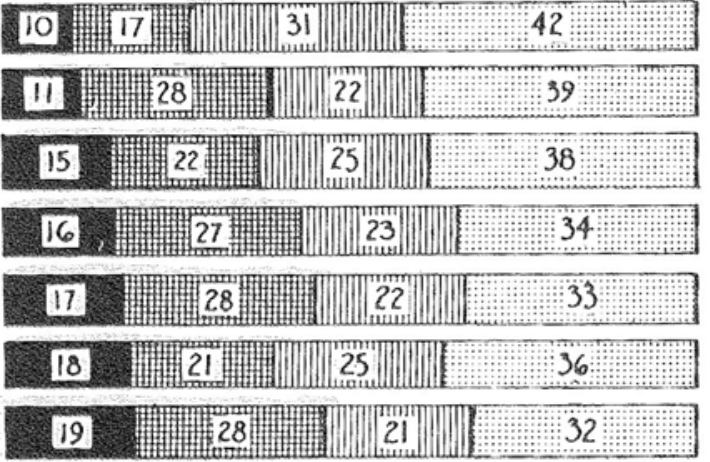

22

33

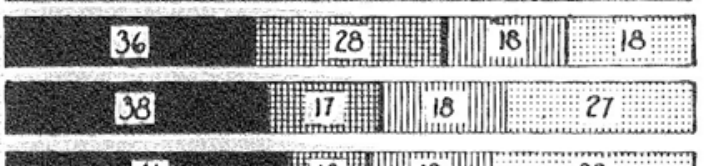

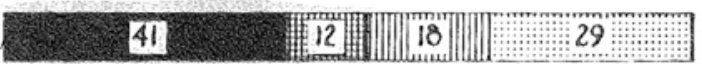

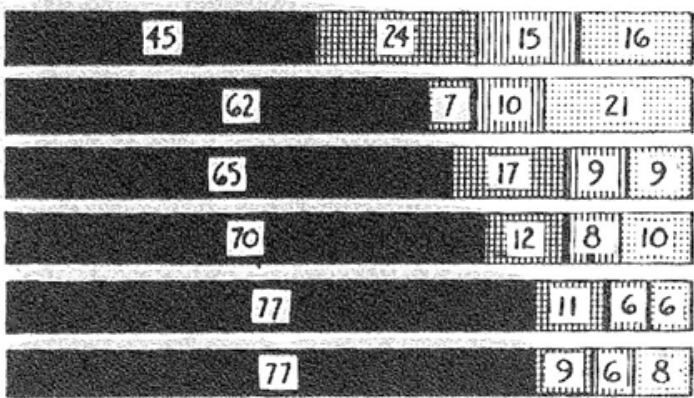

such as Peat and Muck and Bottomland had greater percentages of permanent vegetation.

Sample sizes for data presented in table 3 were calculated in two ways. When crop sequences were assigned to a landscape position, the number of sequences increased to 1,710 because some listed soil types (table rows) included multiple landscape positions. Sixteen percent of all 583 listed soil types included more than one different landscape position. For those instances, the recommended crop rotations were assigned to both landscape positions, with the assumption being that the crop rotation was suitable for that location. For percentage permanent cover, the $16 \%$ of soil types that included two or more different landscape positions were deleted to avoid making assumptions about the relative percentage permanent cover in multiple landscape positions. Recommended rotations for upland outcrops were consistent with other upland landscape positions. With no soil types assigned only to the upland outcrop position, percentage permanent cover data for this position were not available.

Recommended crop rotations were evaluated based on the most frequently recommended sequence for each landscape position and separately by the landscape position for which a particular crop sequence was most frequently indicated (table 4). Crop sequences starting with $\mathrm{C}-\mathrm{C}-\mathrm{O}-$ occurred more frequently than any other combination for bottomlands (55\%), terrace
(51\%), upland level (56\%), and upland sloping $(37 \%)$ areas. For upland outcrop areas, $\mathrm{C}-\mathrm{O}-\mathrm{Cl}-$ was the most common sequence (40\%). The most frequently referenced landscape position was upland sloping areas with $49 \%$ of all assigned positions.

Evaluating table 4 by row totals instead of column totals indicated the most frequent location for each crop sequence. Bottomland and upland sloping areas were the most frequently recommended locations. The truck crop rotation separated most clearly with $87 \%$ of all recommended truck crop rotations occurring on bottomland soils. Of all the $\mathrm{C}-\mathrm{O}-\mathrm{A}-$ recommended rotations, $68 \%$ occurred on upland sloping soils. Other rotations separated to a smaller extent based on landscape position. The rotation $\mathrm{C}-\mathrm{C}-\mathrm{W}-$ was most common in bottomland soils, but this only accounted for 33\% of all C-C-Wrecommendations. Rotations containing oat were more commonly suggested for upland sloping areas than bottomland soils. With several frequencies close to or below 50\%, many suggested crop rotations were suitable across landscape position.

Connecting Historic and Current Soil Conservation Efforts. How applicable are historic soil conservation and crop rotation recommendations from the 1930 s to our current agricultural systems? As demonstrated by the crop data Folken summarized, the committee's recommendations had smaller percentages of intertilled crops and higher percentages of grasslands and pasture than was actually used on the Iowa landscape at the time (Folken 1937, 1938). As noted above, Folken saw these crop recommendations as preliminary and required additional economic and social discussions about their usefulness. The committees' recommendations fit within broader Agricultural Adjustment Administration efforts across United States agriculture regarding stabilizing farmer incomes through crop allocation. For example, Pierre (1946) contains a summary table of recommended acreages of intertilled crops for Illinois, Indiana, Iowa, Missouri, and Ohio that were developed by State Agricultural Production Adjustment committees.

In addition to their crop recommendations, the agricultural committees' efforts link to today's agricultural system through their contributions to establishing soil conservation districts in the state by providing feedback on draft legislation (Folken 1938). Nearly all committees (94\%) supported 


\section{Figure 3}

The number of crop rotation sequences with the number of crops recommended in the 1930 reports.

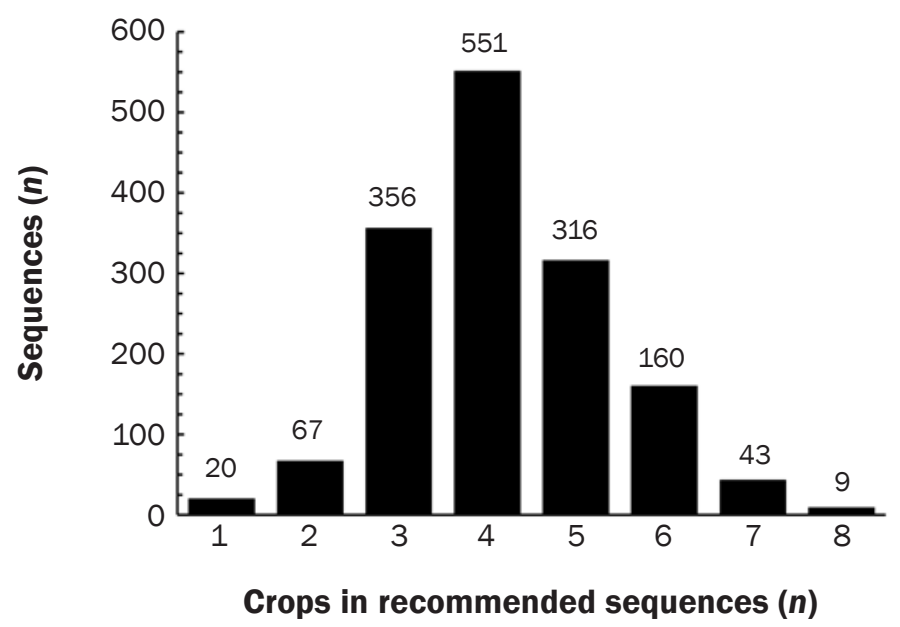

\section{Table 2}

Agricultural committee-recommended cropping rotations from the 1930 s categorized by common leading sequences.

\begin{tabular}{lrc}
\hline Rotation starting with* & Total & Percentage of total \\
\hline C-C-O- & 678 & 45 \\
C-O-Cl- & 361 & 24 \\
C-O-A- & 136 & 9 \\
C-O-other & 92 & 6 \\
C-O-Scl- & 81 & 5 \\
C-C-W- & 58 & 4 \\
C-C-C- & 39 & 3 \\
C-W-other & 20 & 1 \\
C-C-other & 17 & 1 \\
Truck crops $†-$ & 15 & 1 \\
Continuous crop & 12 & 1 \\
Other & 7 & $<1$ \\
Wheat- & 6 & $<1$ \\
\hline Total & 1,522 & 100 \\
\hline
\end{tabular}

*Crops include corn (C), oat (O), clover (Cl), alfalfa (A), sweet clover (Scl), and wheat (W). †Truck crops include fruits and vegetables.

\section{Table 3}

Crop sequence length and percentage permanent cover as recommended by the committees in the 1930 grouped by contemporary landscape position.

\begin{tabular}{|c|c|c|c|c|c|c|}
\hline \multirow[b]{2}{*}{ Landscape position } & \multicolumn{3}{|c|}{ Crop sequence length } & \multicolumn{3}{|c|}{ Percentage permanent cover } \\
\hline & $n$ & Median & Mean & $n$ & Median & Mean \\
\hline Bottomlands & 283 & 4 & 3.99 & 127 & 39 & 43 \\
\hline Terrace & 244 & 4 & 4.12 & 79 & 10 & 17 \\
\hline Upland-level & 306 & 4 & 4.30 & 71 & 9 & 17 \\
\hline Upland-outcrop & 42 & 4 & 3.98 & 0 & - & - \\
\hline Upland-sloping & 835 & 4 & 4.17 & 211 & 30 & 40 \\
\hline
\end{tabular}

having some kind of legislation passed that would help establish soil conservation practices. In 2016, 62\% of farmers somewhat or strongly trusted USDA/NRCS/soil and water conservation district service centers for information about soil and water conservation with 33\% neither trusting nor distrusting these sources (Arbuckle 2017a). Further, 61\% of farmers in 2016 reported having a conservation plan that was created through collaboration with NRCS (Arbuckle 2017a). The agricultural committees were involved in a soil and water conservation legacy that is carried forward today.

Farmers in both time periods recognized erosion was a significant natural resource concern. Almost all of the surveyed committees throughout the state (98\%) noted erosion was a problem in their respective areas. They categorized the erosion as being moderate ( $45 \%$ of all committees), moderate to serious (24\%), and serious $(22 \%)$. Nearly all committees $(95 \%)$ agreed that efforts were needed to reduce erosion, but only $41 \%$ of committees thought soil conservation and erosion could be controlled by individual action. Similarly, all committees indicated maintaining soil fertility and productivity was important, even on soils that were not susceptible to erosion. However, $52 \%$ of committees thought these fertility and productivity goals could be met by individual action (Folken 1938).

Not surprisingly, controlling erosion and maintaining soil productivity remain important to farmers. In 2015, when describing their motivations for using soil and water conservation practices, $73 \%$ of farmers surveyed indicated that maintaining or enhancing productivity was important or very important. A similar $71 \%$ indicated maintaining or improving soil health was an important or very important motivation. As to why soil and water conservation impairment issues continue to be a problem, $72 \%$ of farmers agreed or strongly agreed that tillage increased soil susceptibility to erosion (Arbuckle 2016).

In addition to responses about erosion, farmers in the 1930s and the 2010s provided feedback on trajectories of soil productivity and soil health. The agricultural committees responded to four questions related to their crop rotation and land use recommendations, including their perceptions of (1) the proportion of farmers following their land use recommendations and the proportion of farmers following land use 
practices that would (2) improve soil productivity, (3) maintain soil productivity, or (4) decrease soil productivity. The answers were grouped into four categories: $0 \%$ to $25 \%, 26 \%$ to $50 \%, 51 \%$ to $75 \%$, and $76 \%$ to $100 \%$ (Folken 1938) (table 5).

The agricultural committees described a situation in which soil erosion was a widespread natural resource issue. They perceived farmers in their areas were not always following soil conservation and land use practices that would improve soil over time (table 5). Eighty percent of the committees indicated $50 \%$ or less of farmers in their areas were following the committees' recommended land use practices. Ninety-eight percent of the committees responded that $50 \%$ or less of farmers in their areas were following land use practices that would improve soil productivity over time. Ninety-four percent of the committees perceived $50 \%$ or less of farmers were maintaining productivity, and $68 \%$ of the committees saw $50 \%$ or less of farmers were reducing soil productivity (Folken 1938). In Hardin County, the committee surveyed 175 farmers with similar questions. These farmers responded that approximately one-third of farmers in their county were in each of the three categories of improving (31\%), maintaining (34\%), or reducing soil productivity (35\%) over time (Folken 1938). Folken himself noted these questions were difficult to answer because committees could interpret the questions as if the farmers were actively practicing soil conservation or if they would but were unable to do so due to a current farming situation (Folken 1938).

Farmers surveyed in the 2010s presented a varied picture of soil productivity and improvement as well (table 6). Farmers in 2013 reported similar trajectories of soil health across Iowa and within their respective counties. At the individual farm level, soil health was reported to remain the same (36\%) or be improving (55\%) more frequently than declining (9\%) (Arbuckle 2013). At the county level, the farmer responses from 2013 are similar to the distribution of farmer responses from Hardin County in the 1930s. However, the 2013 farmer responses are higher than the percentages provided by the agricultural committees (Folken 1938).

These survey questions asked farmers to visualize soil health from two different perspectives. First, farmers responded considering their own farm, and second, farmers visualized other groups of farmers at the county

\section{Figure 4}

Number of unique crop rotation recommendations by the county agricultural committees in the 1930 s.

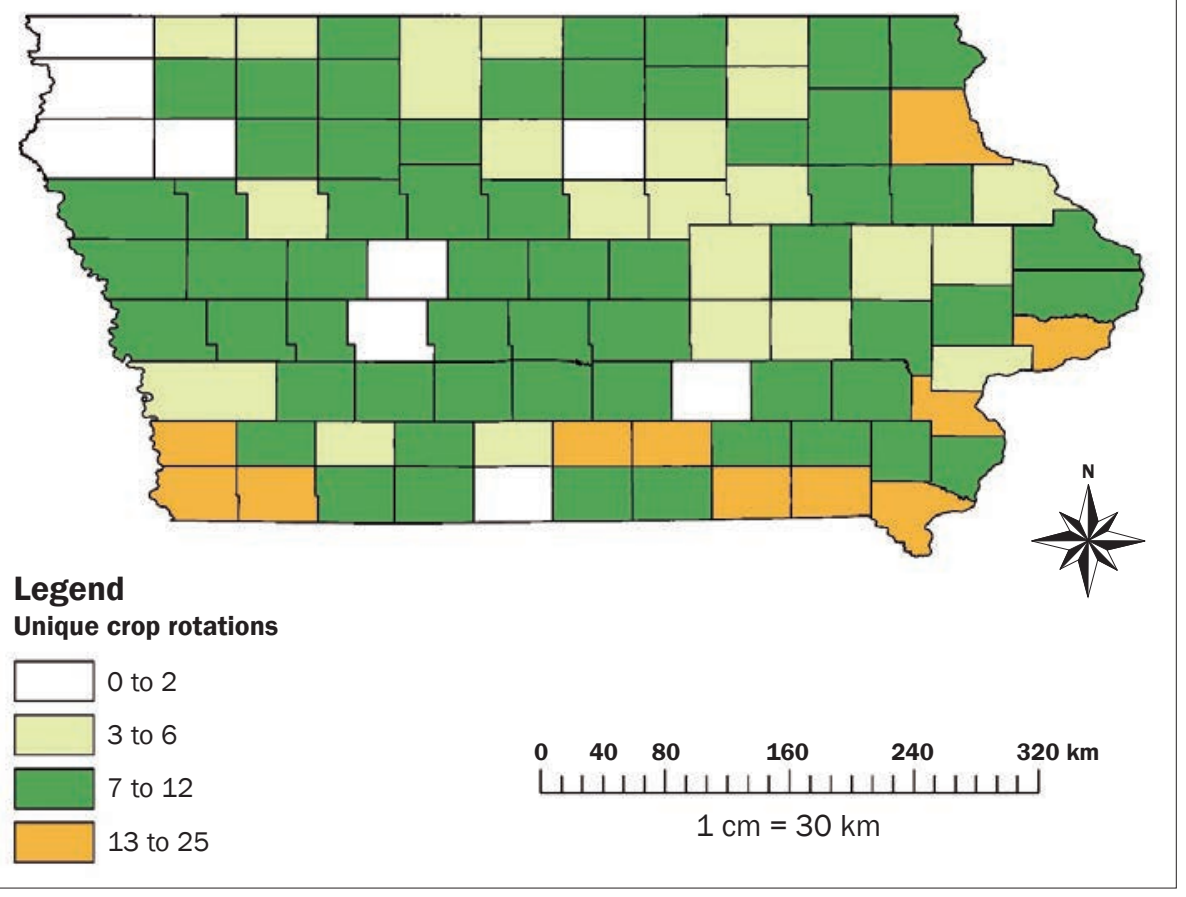

\section{Table 4}

Suggested initial crop rotation sequences as recommended by the committees in the $1930 \mathrm{~S}$ grouped by contemporary landscape position.

\begin{tabular}{|c|c|c|c|c|c|c|}
\hline \multirow[b]{2}{*}{ Rotation starting with* } & \multicolumn{6}{|c|}{ Landscape position† } \\
\hline & B & $\mathbf{T}$ & UL & Uo & US & Total \\
\hline $\mathrm{C}-\mathrm{C}-$ & 10 & 3 & 0 & 0 & 5 & 18 \\
\hline $\mathrm{C}-\mathrm{C}-\mathrm{C}-$ & 21 & 8 & 5 & 2 & 5 & 41 \\
\hline $\mathrm{C}-\mathrm{O}-$ & 12 & 11 & 14 & 3 & 61 & 101 \\
\hline $\mathrm{C}-\mathrm{O}-\mathrm{Scl}-$ & 9 & 11 & 22 & 4 & 48 & 94 \\
\hline $\mathrm{C}-\mathrm{C}-\mathrm{O}-$ & 155 & 124 & 170 & 10 & 307 & 766 \\
\hline C-C-W- & 21 & 15 & 11 & 0 & 16 & 63 \\
\hline $\mathrm{C}-\mathrm{O}-\mathrm{A}-$ & 5 & 17 & 21 & 5 & 103 & 151 \\
\hline $\mathrm{C}-\mathrm{O}-\mathrm{Cl}-$ & 18 & 46 & 56 & 17 & 273 & 410 \\
\hline$C-W-$ & 5 & 4 & 4 & 1 & 9 & 23 \\
\hline Truck crops $\ddagger-$ & 13 & 2 & 0 & 0 & 0 & 15 \\
\hline Wheat- & 4 & 1 & 1 & 0 & 1 & 7 \\
\hline Continuous crop & 9 & 2 & 0 & 0 & 3 & 14 \\
\hline Other & 1 & 0 & 2 & 0 & 4 & 7 \\
\hline Total & 283 & 244 & 306 & 42 & 835 & 1,710 \\
\hline
\end{tabular}

*Crops include corn (C), oat (O), clover (Cl), alfalfa (A), sweet clover (Scl), and wheat (W). †Positions include bottomlands (B), terrace (T), upland-level (UL), upland-outcrop (UO), and upland-sloping (US).

$\ddagger$ Truck crops include fruits and vegetables. 
and state level that did not necessarily include themselves. In surveys, self-assessments tend to lead to what is known as the "better than average" effect (Arbuckle 2017b). For example, when responding to questions about following soil conservation practices, $69 \%$ of farmers self-assessed their ability to control soil erosion as above or far above average compared to farmers in their area (Arbuckle 2017b). This better than average effect does not make these data invalid; rather, the ways in which individuals respond to natural resource questions may vary based on the perspective they are asked to take from a question's structure.

The agricultural committees saw crop rotations as a valued aspect of maintaining soil productivity as evidenced by the range of rotations recommended. Farmers recognize these same benefits today, but they are just as aware of potential economic limitations that Folken (1937) noted. In 2017, 77\% of surveyed farmers agreed or strongly agreed that reductions in mixed grain and livestock farming caused forage and small grain production to be more difficult (Arbuckle 2017b). Seventy percent of farmers agreed or strongly agreed that rotations were perceived as risky because there were not always markets for the crops grown in extended rotations. If these markets were available, $67 \%$ of farmers indicated they would be willing to consider using extended rotations. Developing strong small grains markets was noted as important or very important by 90\% of surveyed farmers (Arbuckle 2017b).

Survey Responses in the Context of Agricultural Change. The similarities in survey responses between the farmers and agricultural committees in the 1930s and 2010 s are in contrast to the changes that occurred in agricultural production between these two time periods. Even with all these changes, farmers in both time periods saw erosion as an important issue; perceived that some soils were improving, remaining the same, and decreasing; and recognized the potential economic limitations to using long-term crop rotations. Iowa was an agricultural state in the 1930s and remains one today. Numerous changes occurred, such as land use, tile drainage, crop yields, technology adoption, and fertilizer use. Throughout the Midwest, increases in soybean production coupled with smaller increases in corn production matched decreases in small grain and grassland production (Jackson 2008).

\section{Table 5}

Folken's (1938) summary of the number of agricultural committee responses to four survey questions.

\begin{tabular}{lllll}
\hline & \multicolumn{4}{l}{ Farmers in the county (\%) } \\
\cline { 2 - 5 } Question & $\mathbf{0}$ to $\mathbf{2 5}$ & $\mathbf{2 6}$ to $\mathbf{5 0}$ & $\mathbf{5 1}$ to $\mathbf{7 5}$ & $\mathbf{7 6}$ to $\mathbf{1 0 0}$ \\
\hline $\begin{array}{l}\text { Following committee } \\
\text { recommendations }\end{array}$ & 39 & 31 & 12 & 5 \\
\hline Is soil productivity... & & & & \\
\hline Improving & 65 & 20 & 3 & 0 \\
Maintaining & 20 & 62 & 6 & 0 \\
Reducing & 16 & 43 & 28 & 1
\end{tabular}

\section{Table 6}

Farmer responses to 2013 survey questions about soil health trajectories in lowa from the lowa Farm and Rural Life Polls (adapted from Arbuckle 2013).

\begin{tabular}{llll}
\hline Question & \multicolumn{3}{l}{ Survey respondents (\%) } \\
\hline Is soil health... & Statewide & County & Individual farm \\
Improving & 38 & 40 & 55 \\
Remaining the same & 38 & 38 & 36 \\
Declining & 24 & 21 & 9 \\
\end{tabular}

A comparison of selected crop and drainage data illustrates that although Iowa was an agricultural state during both time periods, the allocation of land resources changed (table 7). Land in corn and soybean production increased while oat and hay production decreased. Total farmland decreased $10 \%$, but harvested cropland increased $25 \%$. Concurrent with this change, the amount of tile-drained land increased six-fold and land drained by ditches increased by 100,000 ha Tile drainage changed how landscape position affected crop suitability and soil profile water status by increasing areas that might be used for particular production practices (James and Fenton 1993). Multiple factors, including landscape position, soil texture, and precipitation amount and timing, affect whether or not undrained or drained soils produce higher yields in any given year (Nash et al. 2015; Schwab et al. 1966). A similar increase in tile drainage occurred nationwide. In 2012 , $2 \times 10^{7}$ ha were tile drained compared to $3 \times$ $10^{6}$ ha in 1940 (USDA 1940b, 2012c). Even with these changes, there are some broad regional differences in Iowa that existed both in the 1930s and today. Southern Iowa still tends to have a greater area in pasture than north-central or western Iowa (USDA NASS 2016; USGS 2016).

In addition to these acreage changes, crop yields increased. When comparing statewide average crop yields from 1928 to 1937 with data from 2008 to 2017, corn yields quintupled, soybean yields tripled, oat yields tripled, and hay yields doubled (USDA NASS 2018). These increases are approximate values as year-to-year variability occurred. The following values are the lowest and highest average annual corn yields for the two time periods. Farmers from 1928 to 1937 in Iowa were averaging corn yields of between 1.3 and $2.8 \mathrm{Mg} \mathrm{ha}^{-1}$ (assuming shelled corn weights), while farmers from 2008 to 2017 averaged yields from 8.6 to $12.7 \mathrm{Mg} \mathrm{ha}^{-1}$. In these same time periods, statewide oat yields increased from 0.5 to $1.3 \mathrm{Mg} \mathrm{ha}^{-1}$ up to 2.2 and $2.8 \mathrm{Mg} \mathrm{ha}^{-1}$. Soybean yields increased from 0.8 to $1.3 \mathrm{Mg} \mathrm{ha}^{-1}$ up to 3 and $4 \mathrm{Mg}$ $\mathrm{ha}^{-1}$. Hay yields increased from between 2 and $3.6 \mathrm{Mg} \mathrm{ha}^{-1}$ up to 5.6 and $7.8 \mathrm{Mg} \mathrm{ha}^{-1}$ (USDA NASS 2018).

Technology adoption increased, and fertilizer costs rose. Though $90 \%$ of farms reported having an automobile in 1930 and 1940, only $29 \%$ of farms reported a tractor in 1930 and $55 \%$ did so in 1940 , accounting for 66,258 and 128,516 tractors, respectively. In 1940, the total number of farms reporting having a tractor was 117,932 (USDA 1940d). In 2012, 232,016 tractors were reported from 70,810 farms (USDA 2012d). These values reflect both the increased mechanization in agricultural production and the change in the sizes of farm. Fertilizer use, including lime and soil conditioners, cost approximately US $\$ 2.6$ bil- 
Table 7

Cropland use and tile data for lowa for 1938 to 1940 and 2014 to 2016 .

\begin{tabular}{lccll}
\hline & $\mathbf{1 9 3 8}$ to $\mathbf{1 9 4 0}$ & $\mathbf{2 0 1 4}$ to $\mathbf{2 0 1 6}$ & \\
\cline { 2 - 3 } Comparison & Hectares $\times \mathbf{1 0}^{\mathbf{6}}$ & & Source \\
\hline Corn planted & 4.0 & 5.6 & USDA NASS (2017) \\
Soybean planted & 0.4 & 3.8 & \\
Oat planted & 2.4 & 0.05 & \\
Harvested hay & 2.4 & 0.4 & USDA (1940a, 2012b) \\
\hline Total land in farms & 13.8 & 12.4 & \\
Harvested cropland & 8.1 & 9.9 & USDA (1940b, 2012c) \\
Drained by tile & 0.8 & 5.1 & \\
Drained by ditches & 0.6 & 0.7 &
\end{tabular}

lion in 2012 (USDA NASS 2018) compared to commercial fertilizer and liming materials expenses of US\$1.2 million in 1939 (USDA 1940c). When expressed in 2012 dollars, these costs were US\$19.9 million (Bureau of Labor Statistics 2018). Two additional statistics help describe the technology available to Iowa farmers in the 1930s. Motor-trucks were reported on $15 \%$ and $12 \%$ of farms, respectively, in 1930 and 1940. The percentage of farms reporting dwellings lit by electricity increased from $21 \%$ in 1930 to 41\% in 1940 (USDA 1940d).

Adoption of no-till practices occurred after the 1930s, though discussions about moldboard plowing and plowing alternatives occurred at this time (Lal et al. 2007; Nelson 1997). A survey from 1978 and 1979 indicated that less than $2 \%$ of all farm hectares in Iowa were in no-till production (Unger and McCalla 1980). By 2012, this area had increased to $29 \%$ in Iowa (USDA 2012c). As the agricultural committees did not have ready access to no-till planting or modern herbicides in the 1930s, we can only speculate as to how this technology and associated weed control would have affected their recommendations. Certainly, no-till practices can assist in reducing erosion potential, particularly on erosion-prone soils that could have changed the percentages of permanent vegetation summarized by soil series (figure 2).

The agricultural committees in the 1930s suggested crop rotations with multiple crops (an average of four within each). However, these committees thought most farmers were not following their recommendations (table 5). Though farmers in the 2010s were not surveyed in the same way to describe recommended crop rotations, researchers have quantified rotation practices statewide. As Tomer et al. (2017) concluded, based on 2010 to 2015 data, $47 \%$ of Iowa field hectares rotated between corn and soybean, 25\% used a corn/soybean with continuous corn system, and $15 \%$ were in pasture. The remaining $13 \%$ of field hectares comprised various combinations of corn, soybean, perennial, and wheat rotations (Tomer et al. 2017). Continuous corn was not commonly recommended in the 1930s (table 2), and largely because of nitrogen $(\mathrm{N})$ management, it was not frequently suggested during that era. The number of Iowa field hectares exhibiting continuous corn during 2010 to 2015 was 4\% (Tomer et al. 2017).

The agricultural committees used the resources available to them to suggest how farming practices could incorporate crop rotations and land use practices to improve soils. Similarly, today, with expanded technological capabilities, researchers are able to identify multiple soil conservation options that farmers can consider (Jewett and Schroeder 2015; Schulte et al. 2017; Tomer et al. 2017). Many of the recommended practices are similar from the 1930 s, but some are new. Agricultural committees considered conservation practices such as grassed waterways, contour farming, and strip cropping. Grassed waterways and buffer strips using prairie plants are of current interest in Iowa (Schulte et al. 2017). Additional conservation practices that are considered today include controlled drainage, sediment control basins, wetlands, and bioreactors (Tomer et al. 2013). These expanded options relative to conservation practices available in the 1930s increase the potential for maintaining agricultural productivity and protecting soil and water resources.

Overlapping social, economic, and environmental issues continue to shape agricultural systems (Reganold et al. 2011). Addressing these issues comprehensively requires continual refinement in how we approach our agricultural systems through using responsive, adaptive management approaches (Manale 2008; Moore 2009). Collectively, we continue to address land use questions, such as what can be grown and the appropriate production methods, and our responses to these questions continue to change as we learn more about the social, economic, and environmental effects of our previous approaches. Adaptive management is a technique that actively recognizes production decisions must be made under less than ideal conditions as we cannot have every piece of data available that we would like to know (Manale 2008). Farmers in the 1930s and the 2010s practiced adaptive management as evidenced by their recognition that soil and water conservation practices fit within broader economic and social conditions.

\section{Summary and Conclusions}

Farmers in the 1930s and 2010s recognized soil erosion was a natural resource concern. The farmers who met as members of agricultural committees in the 1930s recommended a range of production practices, including using crop rotations. Their results were transcribed and analyzed according to five landscape positions: bottomlands, terraces, and upland areas (slopes, outcrops, and flats). The average number of crops recommended for a rotation was four, with the range being from one to eight. No difference in crop rotation length occurred by landscape position. The two most commonly recommended crop rotations, accounting for $45 \%$ and $24 \%$ of all recommendations, respectively, started with corn-corn-oat $(\mathrm{C}-\mathrm{C}-\mathrm{O}-)$ or corn-oat-clover $(\mathrm{C}-\mathrm{O}-\mathrm{Cl})$ phases. Farmers in both time periods perceived soils were degrading, remaining the same, and improving. The relative frequency in each category changed as farmers considered different geographic scales, including their farm, farmers in the county, and across the state. Agricultural practices have changed over this 80 year period, but the perceptions of how soils are changing remain similar. In both time periods, farmers and researchers presented options that could achieve the timeless goal of maintaining agricultural productivity while preserving soil resources and advancing economic opportunities. The data presented in this study provides an example of historical agricultural land use decision making that remains relevant today. 


\section{Acknowledgements}

The authors would like to acknowledge the Iowa State University Libraries for their assistance with the project, including Lorraine Pellack, head of the Research and Outreach Services Department, Iowa State University, Ames, Iowa; and Megan O'Donnell, data management and science and technology librarian, Iowa State University, Ames, Iowa.

\section{References}

Arbuckle, Jr., J.G. 2013. Iowa farm and rural life poll 2013 summary report. Iowa State University Extension and Outreach PM3061. Ames, IA: Iowa State University Extension and Outreach. https://store.extension.iastate. edu/product/14037.

Arbuckle, Jr., J.G. 2016. Iowa farm and rural life poll 2015 summary report. Iowa State University Extension and Outreach PM3075. Ames, IA: Iowa State University Extension and Outreach. https://store.extension.iastate. edu/product/14502.

Arbuckle, Jr., J.G. 2017a. Iowa farm and rural life poll 2016 summary report. Iowa State University Extension and Outreach SOC3081. Ames, IA: Iowa State University Extension and Outreach. https://store.extension.iastate. edu/product/15093.

Arbuckle, Jr., J.G. 2017b. Iowa farm and rural life poll 2017 summary report. Iowa State University Extension and Outreach SOC3085. Ames, IA: Iowa State University Extension and Outreach. https://store.extension.iastate. edu/product/15322.

Beehler,J., J. Fry,W. Negassa, and A. Kravchenko. 2017. Impact of cover crop on soil carbon accrual in topographically diverse terrain. Journal of Soil and Water Conservation 72(3):272-279, doi:10.2489/jswc.72.3.272.

Bennett, H.H., and W.R. Chapline. 1928. Soil Erosion a National Menace. United States Department of Agriculture Circular 33. Washington, DC: Government Printing Office

Browning, G.M., R.A. Norton, A.G. McCall, and F.G. Bell. 1948. Investigation in erosion control and the reclamation of eroded land at the Missouri Valley Loess Conservation Experiment Station, Clarinda, Iowa, 1931-42. USDA Soil Conservation Service Technical Bulletin 959. Washington, DC: Government Printing Office.

Browning, G.M., C.L. Parish, and J. Glass. 1947. A method for determining the use and limitations of rotation and conservation practices in the control of soil erosion in Iowa. Agronomy Journal 39:65-73.

Bullock, D.G. 1992. Crop rotation. Critical Reviews in Plant Sciences 11(4):309-329.

Bureau of Labor Statistics. 2018. CPI Inflation Calculator. Washington, DC: US Bureau of Labor Statistics. https:// www.bls.gov/data/inflation_calculator.htm.

Cambardella, C.A., T.B. Moorman, S.S. Andrews, and D.L. Karlen. 2004. Watershed-scale assessment of soil quality in the loess hills of southwest Iowa. Soil and Tillage Research 78:237-247.
Chilcott, E.C. 1910. A study of cultivation methods and crop rotations for the Great Plains area. USDA Bureau of Plant Industry Bulletin 187. Washington, DC: Government Printing Office.

County Agricultural Planning Committees. 1937. Iowa State College Extension Service.Ames, IA: Iowa State University

Delate, K., M. Duffy, C. Chase, A. Holste, H. Friedrich, and N. Wantate. 2003.An economic comparison of organic and conventional grain crops in a long-term agroecological research (LTAR) site in Iowa. American Journal of Alternative Agriculture 18(2):59-69.

DeVuyst, E.A., T. Foissey, and G.O. Kegode. 2005. An economic comparison of alternative and traditional cropping systems in the northern Great Plains, USA Renewable Agriculture and Food Systems 21(1):68-73.

Folken, H.G. 1937. County land use planning by Iowa farmers. Iowa State College Extension Service Circular 233. Ames, IA: Iowa State University.

Folken, H.G. 1938. Summary of reports of the county agricultural planning committees on questions relating to soil conservation districts. Ames, IA: Iowa State University.

Gaudin, A.C.M., T.N. Tolhurst, A.P. Ker, K. Janovicek, C. Tortora, R.C. Martin, and W. Deen. 2015. Increasing crop diversity mitigates weather variations and improves yield stability. PloS ONE 10(2):e0113261.

Grandy, A.S., and G.P. Robertson. 2007. Land-use intensity effects on soil organic carbon accumulation rates and mechanisms. Ecosystems 10:58-73.

Hays, W.M., A. Boss, A.D. Wilson, and T.P. Cooper. 1912 Farm management: Organization of research and teaching. USDA Bureau of Plant Industry Bulletin 236. Washington, DC: Government Printing Office.

Helms, D. 1992. The development of the land capability classification. In Readings in the History of the Soil Conservation Service, ed. D. Helms, 60-73. Washington, DC: Soil Conservation Service. https://www.nrcs. usda.gov/wps/portal/nrcs/detail/national/about/ history/?cid=nrcs143_021436.

Helms, J.D., G.A. Pavelis, S. Argabright, R.G. Cronshey, and H.R. Sinclair Jr. 1996. National soil conservation policies: A historical case study of the driftless area Agricultural History 70(2):377-394.

Iowa Farm and Rural Life Poll. 2018. Iowa State University Sociology Extension. Ames, IA: Iowa State University. https://ext.soc.iastate.edu/programs/ iowa-farm-and-rural-life-poll/.

Jackson, L.L. 2008. Who 'designs' the agricultural landscape? Landscape Journal 27:1-08.

James, H.R., and T.E. Fenton. 1993. Water tables in paired artificially drained and undrained soil catenas in Iowa Soil Science Society of America Journal 57:774-781.

Janzen, H.H. 2001. Soil science on the Canadian prairies Peering into the future from a century ago. Canadian Journal of Soil Science 81:489-503.

Jewett, J.G., and S. Schroeder. 2015. Continuous living cover manual. Green Lands Blue Waters. http://
greenlandsbluewaters.net/CLC_manual_printfriendly_ FINAL.pdf.

Jokela, W., J. Posner, J. Hedtcke, T. Balser, and H. Read. 2011. Midwest cropping system effects on soil properties and on a soil quality index. Agronomy Journal 103:1552-1562.

Karlen, D.L., M.D. Duffy, and T.S. Colvin. 1995. Nutrient, labor, energy, and economic evaluations of two farming systems in Iowa. Journal of Production Agriculture 8:540-546.

Karlen, D.L., N.J. Goeser, K.S. Veum, and M.A. Yost. 2017 On-farm soil health evaluations: Challenges and opportunities. Journal of Soil and Water Conservation 72(2):26A-31A, doi:10.2489/jswc.72.2.26A.

Karlen, D.L., E.G. Hurley, S.S. Andrews, C.A. Cambardella, D.W. Meek, M.D. Duffy, and A.P. Mallarino. 2006. Crop rotation effects on soil quality at three northern corn/ soybean belt locations. Agronomy Journal 98:484-495.

Karlen, D.L., G.E. Varvel, D.G. Bullock, and R.M. Cruse. 1994. Crop rotations for the 21st century. Advances in Agronomy 53:1-45.

Klingebiel, A.A., and P.H. Montgomery. 1961. Landcapability classification. Agriculture Handbook no. 210. Soil Conservation Service. USDA. Washington, DC: Government Printing Office.

Lal, R., D.C. Reicosky, and J.D. Hanson. 2007. Evolution of the plow over 10,000 years and the rationale for no-till farming. Soil and Tillage Research 93:1-12.

Liebman, M., and E. Dyck. 1993. Crop rotation and intercropping strategies for weed management. Ecological Applications 3(1):92-122.

Liebman, M., and L.A. Schulte. 2015. Enhancing agroecosystem performance and resilience through increased diversification of landscapes and cropping systems. Elementa: Science of the Anthropocene 3:000041, doi:10.12952/journal.elementa.000041.

Manale, A.P. 2008. Steering conservation's course using adaptive management. Journal of Soil and Water Conservation 63(6):183A-184A, doi:10.2489/ jswc.63.6.183A

Montgomery, D.R. 2007. Soil erosion and agricultural sustainability. Proceedings of the National Academy of Sciences 104(33):13268-13272

Moore, K.M., ed. 2009. The Sciences and Art of Adaptive Management: Innovating for Sustainable Agriculture and Natural Resource Management. Ankeny, IA: Soil and Water Conservation Society.

Nash, P.R., K.A. Nelson, and P.P. Motavalli. 2015. Corn response to drainage and fertilizer on a poorly drained, river bottom soil. Agronomy Journal 107:1801-1808.

Necpálová, M., D. Li, G. Lanigan, I.A. Casey, W. Burchill, and J. Humphreys. 2013. Changes in soil organic carbon in a clay loam soil following ploughing and reseeding of permanent grassland under temperate moist climatic conditions. Grass Forage Science 69:611-624. 
Nelson, P.J. 1997. To hold the land: Soil erosion, agricultural scientists, and the development of conservation tillage techniques. Agricultural History 71(1):71-90.

Page, J.B., and C.J. Willard. 1947. Cropping systems and soil properties. Soil Science Society of America Journal 11:81-88.

Pierre, W.H. 1946. A look forward in the management of Corn Belt soils. Soil Science Society of America Journal 10:3-8.

R Core Team. 2017. R: A language and environment for statistical computing. Vienna, Austria: R Foundation for Statistical Computing. https://www.r-project.org/.

Reganold, J.P., D. Jackson-Smith, S.S. Batie, R.R. Harwood, J.L. Kornegay, D. Bucks, et al. 2011. Transforming US agriculture. Science 332(6030):670-671.

Reicosky, D.C. 2015. Conservation tillage is not conservation agriculture. Journal of Soil and Water Conservation 70(5):103A-108A, doi:10.2489/jswc.70.5.103A.

Reicosky, D.C., W.D. Kemper, G.W. Langdale, C.L. Douglas Jr., and P.E. Rasmussen. 1995. Soil organic matter changes resulting from tillage and biomass production. Journal of Soil and Water Conservation 50(3):253-261.

Riecken, F.F., W.H. Allaway, and G.D. Smith. 1948. Some soil classification and mapping problems in the Wisconsin drift area of Iowa. Soil Science Society of America Journal 12:432-440.

Schulte, L.A., J. Niemi, M.J. Helmers, M. Liebman, J.G. Arbuckle, D.E. James, et al. 2017. Prairie strips improve biodiversity and the delivery of multiple ecosystem services from corn-soybean croplands. Proceedings of the National Academy of Sciences 114(42):11247-11252.

Schwab, G.O., G.S. Taylor, J.L. Fouss, and E. Stibbe. 1966. Crop response from tile and surface drainage. Soil Science Society of America Journal 30(5):634-637.

Soil Conservation Service. 1955. Our Productive Land. Agriculture Information Bulletin 106. Washington, DC: Government Printing Office,

Soil Series Extent Explorer. 2018. California Soil Resource Lab UC Davis. https://casoilresource.lawr.ucdavis.edu/see/.

Soil Survey Staff. 2018. Web Soil Survey. Washington, DC: USDA Natural Resources Conservation Service. https://websoilsurvey.sc.egov.usda.gov/.

Tomer, M.D., D.E. James, and C.M.J. Sandoval-Green. 2017. Agricultural conservation planning framework: 3. Land use and field boundary database development and structure. Journal of Environmental Quality 46:676-686.

Tomer, M.D., S.A. Porter, D.E. James, K.M.B. Boomer, J.A. Kostel, and E. McLellan. 2013. Combining precision conservation technologies into a flexible framework to facilitate agricultural watershed planning. Journal of Soil and Water Conservation 68(5):113A-120A, doi:10.2489/jswc.68.5.113A.

Unger, P.W., and T.M. McCalla. 1980. Conservation tillage systems. Advances in Agronomy 33:1-58.

US Census Bureau. 2017. TIGER Products. Washington, DC: US Census Bureau https://www.census.gov/geo/ maps-data/data/tiger.html.
USDA. 1940a. Census of Agriculture - Iowa. State Table 1. Farms and farm acreage. Ithaca, NY: Cornell University. http://usda.mannlib.cornell.edu/usda/ AgCensusImages/1940/01/16/1264/Table-01.pdf.

USDA. 1940b. Census of Drainage - United States Summary. Table 17 Land in drainage enterprises classified by condition and by use. Ithaca, NY: Cornell University. http://usda.mannlib.cornell.edu/usda/ AgCensusImages/1940/04/06/1352/Table-17.pdf.

USDA. 1940c. Census of Agriculture - Iowa. State Table 8. Cooperative selling and purchasing, and specified farm expenditures: 1909 to 1939. Ithaca, NY: Cornell University. http://usda.mannlib.cornell.edu/usda/ AgCensusImages/1940/01/16/1264/Table-08.pdf.

USDA. 1940d. Census of Agriculture - Iowa. State Table 11. Specified farm machinery and facilities, by tenure of operator: 1940, 1930, and 1920. Ithaca, NY: Cornell University. http://usda.mannlib.cornell.edu/usda/ AgCensusImages/1940/01/16/1264/Table-11.pdf.

USDA. 2012a. Table 50. Land use practices by size of farm: 2012. Census of Agriculture 2012. https://www. agcensus.usda.gov/Publications/2012/Full_Report/ Volume_1,_Chapter_1_US/st99_1_049_050.pdf.

USDA. 2012b. Table 1. State summary highlights: 2012. Census of Agriculture 2012. https://www.agcensus. usda.gov/Publications/2012/Full_Report/Volume_1, Chapter_2_US_State_Level/st99_2_001_001.pdf.

USDA. 2012c. Table 50. Land use practices by size of farm: 2012. Census of Agriculture 2012 Iowa results. https:// www.agcensus.usda.gov/Publications/2012/Full_ Report/Volume_1,_Chapter_1_State_Level/Iowa/ st19_1_049_050.pdf.

USDA. 2012d. Table 48: Selected machinery and equipment on operation: 2012 and 2007. Census of Agriculture 2012 Iowa results. https://www.agcensus.usda. gov/Publications/2012/Full_Report/Volume_1, Chapter_1_State_Level/Iowa/st19_1_045_048.pdf.

USDA NASS (USDA National Agricultural Statistics Service). 2016. CropScape Cropland Data Layer. Washington, DC: USDA National Agricultural Statistics Service. https://nassgeodata.gmu.edu/CropScape/.

USDA NASS. 2018. QuickStats Database. Washington, DC: USDA National Agricultural Statistics Service. https:// quickstats.nass.usda.gov.

USDA NRCS (USDA Natural Resources Conservation Service). 2017a. Official Soil Series Descriptions (OSDs). Washington, DC: USDA Natural Resources Conservation Service. https://soilseries.sc.egov.usda. gov/osdname.aspx.

USDA NRCS. 2017b. Published Soil Surveys for Iowa. Washington, DC: USDA Natural Resources Conservation Service. https://www.nrcs.usda.gov/wps/ portal/nrcs/surveylist/soils/survey/state/?stateId=IA.

USGS (US Geological Survey). 2016. National Gap Analysis Program Land Cover Data Portal. Reston, VA: US Geological Survey. https://gapanalysis.usgs.gov/ gaplandcover/data/download/.
Veenstra, J.J., and C.L. Burras. 2015. Soil profile transformation after 50 years of agricultural land use. Soil Science Society of America Journal 79:1154-1162.

Walker, R.H., and P.E. Brown. 1936. Soil erosion in Iowa. Special Report 2. Ames, IA: Iowa State College Agricultural Experiment Station. https://lib.dr.iastate. edu/specialreports $/ 2$.

Wickings, K., A.S. Grandy, and A.N. Kravchenko. 2016. Going with the flow: Landscape position drives differences in microbial biomass and activity in conventional, low input, and organic agricultural systems in the Midwestern US. Agriculture, Ecosystems and Environment 218:1-10. 